\title{
IMPACT OF GENDER ON SELF-EFFICACY: EVIDENCE FROM INDONESIA'S KARO TOURISM
}

\author{
Nurlisa GINTING* \\ Universitas Sumatera Utara, Faculty of Engineering, Department of Architecture, Medan, Indonesia, e-mail: nurlisa@ usu.ac.id; \\ N. Vinky RAHMAN \\ Universitas Sumatera Utara, Faculty of Engineering, Department of Architecture, Medan, Indonesia, e-mail: n.vinky@usu.ac.id;
}

\author{
Achmad Delianur NASUTION
}

Universitas Sumatera Utara, Faculty of Engineering, Department of Architecture, Medan, Indonesia, e-mail: a.delianur@usu.ac.id;

Citation: Ginting, N., Rahman, N.V., \& Nasution, A.D. (2022). IMPACT OF GENDER ON SELF-EFFICACY: EVIDENCE FROM INDONESIA'S KARO TOURISM. GeoJournal of Tourism and Geosites, 40(1), 218-224. https://doi.org/10.30892/gtg.40126-822

\begin{abstract}
Self-efficacy in tourist destination can influence the tourists' level of satisfaction which may depend on how much the destination has fulfilled their needs. This research aims at investigating the relationship between gender preference and self-efficacy in tourist destination in Karo regency. Female tourists are usually significantly different, in which male's selfefficacy tend to be higher than female's. This research used a qualitative and quantitative method to obtain the varieties of perception, such as accessibility, comfort, confidence, and safety. The result reveals self-efficacy isindeed different for local male and female visitors; however, the male and female tourists from abroad do not indicate significant difference. The level of self-efficacy (LSE) for females is not always lower than males and, even, the activities cannot limit the LSE for males and females. The tourists' activities in the masculine category proved that the females' SE is higher than males. However, the males' SE proved to be higher than females are only found among local people; however, the tourists's SE between males and females look the same. In the development of tourism which is based on the tourists' SE, preference of gender does not need to be considered; however, if it is done on the basis locals' SE, then the preference of gender is really needed.
\end{abstract}

Key words: gender preference, self-efficacy, Karo regency, tourism

$* * * * * *$

\section{INTRODUCTION}

Tourism becomes a multi-sector industry that rapidly grows in recent years. Also, tourism becomes a tremendous resource of income for many countries (Stratan et al., 2015), especially for developing countries to generate their economy (Samimi et al., 2011). Karo regency can be a potential industry in tourism and may improve the economy of the regency, which is known for its most popular tourist destinations in North Sumatra Province as well as in Indonesia. It owns a variety of natural, cultural, and artificial attractions for tourists. It also has moderate weather, mountains, volcanoes, Brastagi city, Lau Kawar lake, Sipiso-Piso waterfall, traditional Lingga Village, among others. However, its tourist objects are improperly managed and maintained; all this brings impacts to the local and international tourists' optimal leisure and satisfaction. The perception of visitors and residents is essential in tourism since their good or bad impression affects their satisfaction for a tourist destination (Stedman, 2002; Wang and Xu, 2015; Ginting, 2016). Self-efficacy (henceforth SE), in this case, can be considered to play a vital role in the stimulation of both good and bad perception (Ginting et al., 2017). The SE refers to a person's belief about his ability to well perform an activity in a place (Bandura, 1997). A person who feels satisfied with a place can perform all his activities leisurely (Twigger-Ross et al., 2003). So naturally, if the SE for a place is high, then the satisfaction to such place is also high. Some studies suggest that gender has a relationship to SE for a place (Propst and Koesler, 1998; Hallak et al., 2014; Hallak et al., 2015; Ghanian et al., 2017), in which male's SE, especially his self-confidence, in outdoor is higher than female's one. All this is caused by the differences in behavior between male and female. Females tend to be more emotional, empathetic, gentle, and sensitive, however, malesare more logical, confident, and assertive (Hallak et al., 2014; Ghanian et al., 2017). Since the standard of male's and female's SE is different, therefore, such standard needs to be further investigated.

The SE is someone's belief in his/her ability to do things (Bandura, 1997; Gist and Mitchell, 1992; Gu and Ryan, 2008; Wang and Chen, 2015) and can be achieved if an environment has supporting facilities for him/her to do activities or, at least,he/she is not interferedin spending their leisure (Bandura, 1997). With reference to tourism, the SE may be achieved if tourist destinations can provide a sense of satisfaction for foreign tourists (henceforth FTs) and local tourists (henceforth LRs) (Ginting, 2018). Therefore, anoperator of a tourist destination (henceforth TD) is required to manage his destination to meet the FTs' and LRs' needs and to make them feel satisfied with the TD.

The SE consists of four aspects, for instance, confidence, comfort, safety, and accessibility (Twigger-Ross and Uzzell, 1996; Eusuf et al., 2014). A person is stimulated to be confidentt if he/she believes he/she can do his/her activities without

\footnotetext{
* Corresponding author
} 
any hindrance (Hung and Petrick, 2012). In the context of tourism, confidence can be marked by complete and accurate information about the tourist attractions that can be obtained from the information centre, website, or other sources, so that an FT or an LR does not hesitate to do their activities there (Ginting et al., 2017). If such information can be easily obtained, then the FTs and LRs will be interested in visiting a TD. Comfort can be seen when either FTs or LTs show as well as express their satisfaction with the atmosphere of TD they stay. An uncomfortable TD will, for example, reduce FTs' and LTs' SE and give them a negative impression to the TD (Twigger-Ross and Uzzell, 1996; Ujang, 2017). Comfort can, in tourism, be measured by the TD's surroundingsof physical conditions such as landscape, pedestrian path, and signage (Ginting, 2016). Safety is the one which is the most important factor not only in SE but also in tourism. It affects the FTs' and LTs' decision whether to visit or not a TD and they will avoid a TD if they think the TD is not safe (Amir et al., 2015). Safety contributes for tourists to make their SE and, when the SE is proved to be safe, they then do their activities; unluckily, no safety in the TD can significantly influence FTs' and LTs' decision to come and to spend their days since they do not feel comfortable with the TD (Ginting, 2018). In this current research, researchers focused on four variables, i.e., accessibility, comfort, confidence, and safety, to reveal the impacts of gender on self-efficacy and to support tourism (Table 1). The variables are believed to provide a sense of satisfaction for local and international tourists and residents.

Table 1. Variables of Self-efficacy Principle

\begin{tabular}{|l|l|l|l|}
\hline \multicolumn{1}{|c|}{ Confidence } & \multicolumn{1}{|c|}{ Comfort } & \multicolumn{1}{c|}{ Safety } & \multicolumn{1}{c|}{ Accessibility } \\
\hline -Respondents' perception on & -Respondents' perceptions on & -Respondents' perceptions on & -Quality of pedestrian paths \\
activities in the research areas & comfort in the research areas & -Sufficient public transportation \\
-Respondents' perceptions on new & -Provision of dust bins & -Provision of street lights & -Sufficion \\
experiences and insights gained & -Provision of public toilets & & \\
-Provision of the information center & -Provision of public seats & & \\
\hline
\end{tabular}

\section{MATERIALS AND METHODS}

The study was conducted in Karo regency (henceforth KR) which is widely known for its nature and cultural heritage. Five unique TDs, such as Pasar Buah, Bukit Gundaeling, Air Terjun Sipiso-Piso, Desa Lingga, and Bukit Kubu (Figure 1), were chosenon the basis of pilot research by the students of Architecture Department, Universitas Sumatera Utara. Firstly, the Pasar Buah (Fruit Market) sells not only fruits but also flowers, souvenirs, and even pets in which all of the itemsare locally branded. It is a recommended place to visit when FTs and LTs are visiting Berastagi. The Bukit Gundaling (Gundaling Hill) is the highest plateau in KR and the best place to view both of Sinabung and Sibayak mounts. Many tourists come to the TD to see its beauty. The Air Terjun Sipiso-Piso (Sipiso-Piso Waterfall) becomes not only the leading TD in KR but also one of geo-sites in Toba Caldera Geo-park. It is precisely located in Geoarea of Haranggaol and was historically formed from the Toba Caldera supervolcano eruption in 74 thousand years ago. The Desa Lingga (Lingga Village) is a historical village having Karonese traditional houses that still stand strong for over 250 years old; unfortunately, there are only four traditional houses left in the village. Lastly, the Bukit Kubu (Kubu Hill) is a grassy open space facilitated by private party. The TD can be used to play soccer, kite, bubble, and many more.

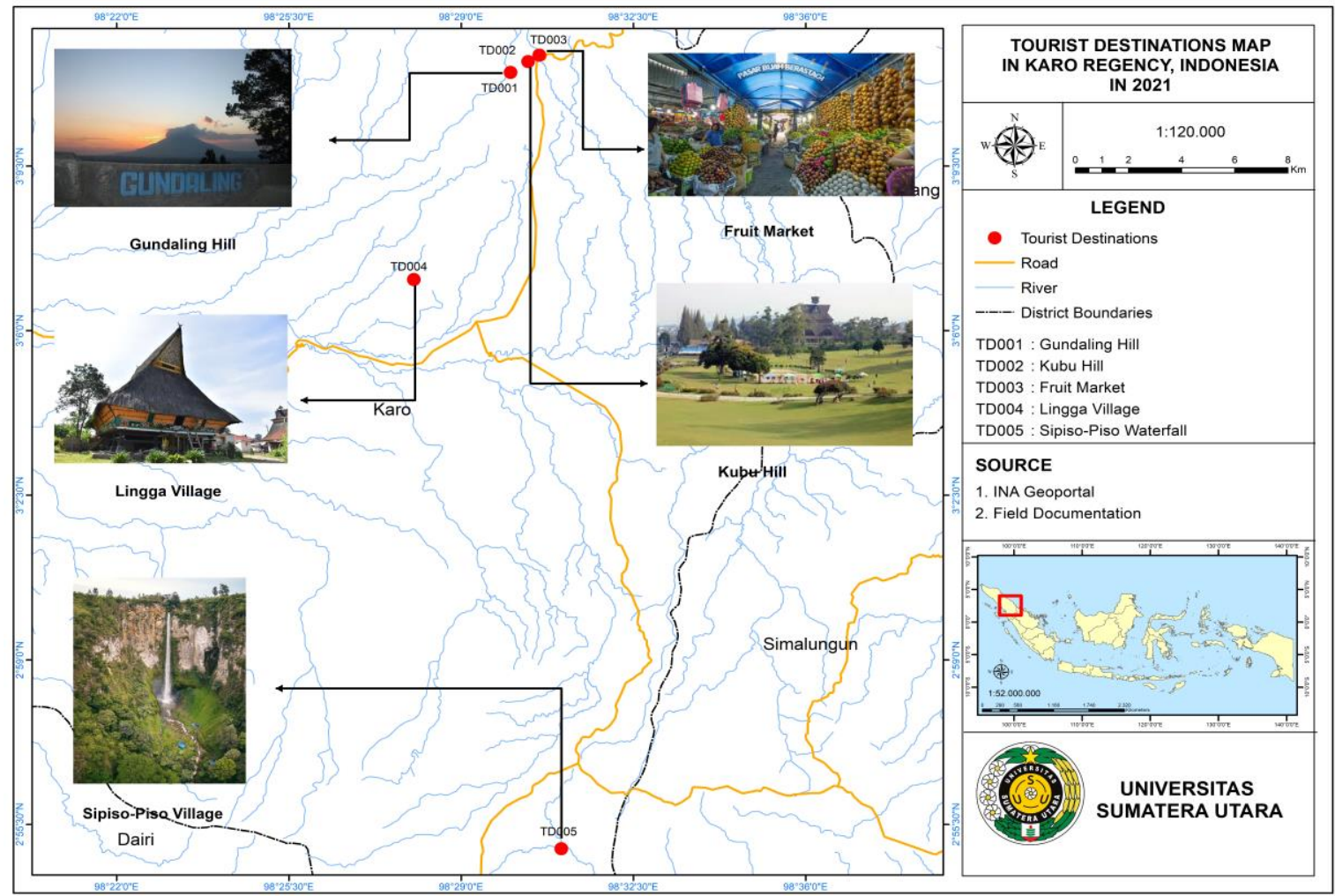

Figure 1. Research Areas (Source: own elaboration) 
The research used the mixed methods to obtain the respondents' perception on their SE for TDs in KR (Figure 2). The quantitative method employed the questionnaires (Table 2) for 360 respondents. To collect different perception and attitudes, the questionnaires were distributed in five samples of research locations and filled by FTs and LTs with the ratio of 50:50. As for the paper would only discuss the different perception between male and female respondents, the ratio is not 50:50 or 180:180 but 176:192 respectively.

In the Pasar Buah, more female respondents were chosen but in the Desa Lingga, more male respondents were ditermined. In the qualitative method, the observation in the research areas was conducted with the aims to collect the physical data, such as physical characteristics, traditional buildings, facilities, the street circulation, pedestrian paths, people activities, among others. Deep interviews with eight stakeholders were also conducted in the areas.

Table 2. Indicators and statements of self-efficacy

\begin{tabular}{|c|c|c|}
\hline No & Indicators & Statements \\
\hline SEF01 & \multirow{6}{*}{ Confidence } & I can do my activity \\
\hline SEF02 & & The best place to do the things I want \\
\hline SEF03 & & Gives new experience and insights \\
\hline SEF04 & & The information that got from this place is same or positive \\
\hline SEF05 & & I would recommend this place to others \\
\hline SEF06 & & There are information center \\
\hline SEF07 & \multirow{4}{*}{ Comfort } & I feel comfortable \\
\hline SEF08 & & There are trash bins \\
\hline SEF09 & & There are seat facilities \\
\hline SEF10 & & The condition of public toilets is good and sufficient \\
\hline SEF11 & \multirow{2}{*}{ Safety } & I feel safe \\
\hline SEF12 & & There are street lights \\
\hline SEF13 & \multirow{3}{*}{ Accessibility } & There are good pedestrian path \\
\hline SEF14 & & There are good public transportation \\
\hline SEF15 & & The condition of the parking lot is good and sufficient \\
\hline
\end{tabular}

Table 3. Gender, age and educational background of respondents

\begin{tabular}{|l|c|c|c|c|c|c|c|c|c|c|c|}
\hline Gender & \multicolumn{2}{|c|}{ PB } & \multicolumn{2}{c|}{ BG } & \multicolumn{2}{c|}{ AS } & \multicolumn{2}{c|}{ DL } & \multicolumn{2}{c|}{ BK } & $\%$ \\
\hline & L & T & L & T & L & T & L & T & L & T & \\
\hline Male & 13 & 15 & 20 & 18 & 21 & 19 & 21 & 24 & 27 & 14 & $53 \%$ \\
\hline Female & 23 & 21 & 16 & 18 & 15 & 17 & 15 & 12 & 9 & 22 & $47 \%$ \\
\hline \multirow{2}{*}{ Age } & \multicolumn{2}{|c|}{ PB } & \multicolumn{2}{|c|}{ BG } & \multicolumn{2}{|c|}{ AS } & \multicolumn{2}{|c|}{ DL } & \multicolumn{1}{c|}{ BK } & $\%$ \\
\cline { 2 - 12 } & L & T & L & T & L & T & L & T & L & T & \\
\hline $18-24$ & 10 & 15 & 17 & 14 & 12 & 18 & 4 & 17 & 8 & 15 & $36 \%$ \\
\hline $25-49$ & 17 & 18 & 12 & 18 & 19 & 16 & 18 & 12 & 21 & 16 & $46 \%$ \\
\hline $50-64$ & 7 & 3 & 5 & 4 & 5 & 2 & 12 & 7 & 5 & 5 & $15 \%$ \\
\hline $65+$ & 2 & 0 & 2 & 0 & 0 & 0 & 2 & 0 & 2 & 0 & $2 \%$ \\
\hline \multirow{2}{*}{ Edu } & PB & \multicolumn{1}{|c|}{ BG } & \multicolumn{2}{|c|}{ AS } & DL & BK & $\%$ \\
\cline { 2 - 11 } & L & T & L & T & L & T & L & T & L & T & \\
\hline HS & 29 & 10 & 31 & 10 & 32 & 14 & 30 & 4 & 27 & 7 & $54 \%$ \\
\hline UG & 7 & 18 & 5 & 20 & 4 & 21 & 6 & 27 & 9 & 26 & $40 \%$ \\
\hline G & 0 & 8 & & 6 & & 1 & & 5 & & 3 & $6 \%$ \\
\hline
\end{tabular}

The eight stakeholders are local figures, government, academics, travel agencies, and hotel association, who are directly or indirectly involved in tourism in the regency. The results from the questionnaires were then processed statistically with SPSS 20 to obtain quantitative data that was used in the SE assessment. The results were analyzed quantitatively using the percentages and average value in the either graphs or tables. The results from quantitative and qualitative data which were combined and triangulated to seek the convergence were described and interpreted on the basis of literature review; after all, the overall conclusion was made.

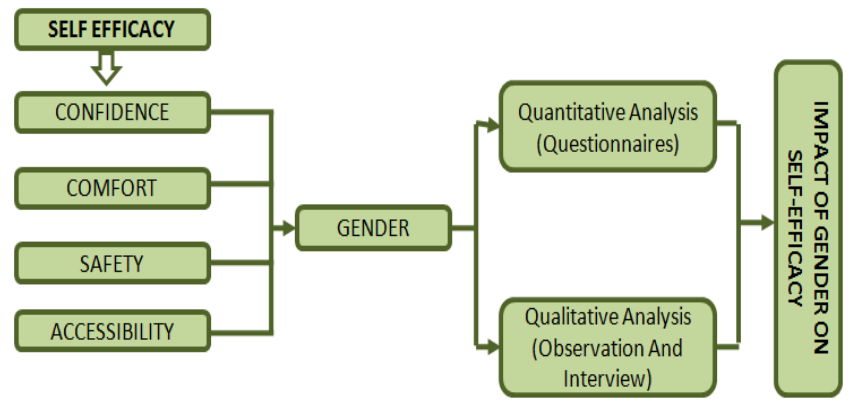

Figure 2. Flow Chart Research

\section{RESULTS AND DISCUSSION}

\section{Respondents}

In this study, the respondent's profile was classified into gender, age, and education. Respondent profile is important to know because someone with a lower education has lower SE than any other person who has higher education (Schwarzer, 2014; Piperopoulos and Dimov, 2015; Stajkovic et al., 2018). Questionnaires were distributed to 360 respondents in the study area. Each TD was represented by 72 respondents, with a composition of 36 residents and 36 tourists. There were 192 male respondents and 168 female ones (see Table 3). Most foreign tourists (FTs) came from Asia $(76 \%)$ and Europe (21\%). The majority age of respondents was between $25-49$ years $(46 \%)$ (Table 3), followed by 18-24 years old (36\%), 50-64 (15\%), and 65+ (2\%). With reference to educational background, 54\% respondents were graduated from high schools (mostly dominated by the local residentswhose educational level was lower than the tourists (see Table 3). Around $83 \%$ of the local residents were graduated from high schools, and $17 \%$ are studying undergraduate but none of the local residents have a bachelor's degree. While $25 \%$ of tourists have graduated from high school, $62 \%$ are currently studying for a bachelor's degree, and $13 \%$ have a bachelor's degree.

\section{Self-Efficacy Principle}

The average score of the questionnaire survey in Table 4 shows differences in the perception of respondents between men and women on the SE principle. Mostly the respondents feel comfortable and recommend tourist destinations to others.

\section{Confidence}

A good TD is the one in which tourists can perform their activities without any difficulties (Wang and Xu, 2015). All respondents, males and females, locals and tourists, claimed to be able to perform their activities properly in the five TDs (see SEF01 in Table 4). There were no significantly different opinions between males and females. Although the respondents thought they could do activities properly, the residents, especially those living in Bukit Gundaling and Pasar 
Buah, do not feel that the place is the most appropriate for doing activities (see SEF02 in Table 4). Locals tended to less appreciate their place but the tourists did. Locals tend to respond negatively to tourism activities in their place because they are more perceive towards the losses they generated than the profits they got (Guo et al., 2014). The respondents stated that the TDs' operators provided enough and good experience and information (see SEF03 in Table 4).

Table 4. The perception of male and female respondent on self-efficacy

\begin{tabular}{|c|c|c|c|c|c|c|c|c|c|c|c|c|c|c|c|c|c|c|c|c|c|}
\hline \multirow{3}{*}{ NO } & \multicolumn{4}{|c|}{ BUKIT GUNDALING } & \multicolumn{4}{|c|}{ BUKIT KUBU } & \multicolumn{4}{|c|}{ PASAR BUAH } & \multicolumn{4}{|c|}{ TERJUN } & \multicolumn{4}{|c|}{ DESA LINGGA } & \multirow{3}{*}{ MEAN } \\
\hline & \multicolumn{2}{|c|}{ LOCAL } & \multicolumn{2}{|c|}{ TOURIST } & \multicolumn{2}{|c|}{ LOCAL } & \multicolumn{2}{|c|}{ TOURIST } & \multicolumn{2}{|c|}{ LOCAL } & \multicolumn{2}{|c|}{ TOURIST } & \multicolumn{2}{|c|}{ LOCAL } & \multicolumn{2}{|c|}{ TOURIST } & \multicolumn{2}{|c|}{ LOCAL } & \multicolumn{2}{|c|}{ TOURIST } & \\
\hline & $\mathrm{M}$ & $\mathrm{F}$ & M & $\mathrm{F}$ & $\mathrm{M}$ & $\mathrm{F}$ & $M$ & $\mathrm{~F}$ & $M$ & $\mathrm{~F}$ & $\mathrm{M}$ & $\mathrm{F}$ & $\mathrm{M}$ & $\mathrm{F}$ & M & $\mathrm{F}$ & $\mathrm{M}$ & $\mathrm{F}$ & $\mathrm{M}$ & $\Gamma$ & \\
\hline 801 & .45 & 94 & & 3.22 & 37 & 44 & 3.36 & 3.45 & 08 & 3.13 & 3.27 & 3.52 & 24 & 3.20 & 3.05 & 3.35 & 48 & 3.07 & 3.29 & 58 & 27 \\
\hline EF0 & 25 & 63 & 17 & 3.17 & 22 & 3.33 & 3.21 & 3.36 & .92 & 2.78 & 3.13 & 14 & .48 & 3.13 & 2.89 & 3.06 & 3.14 & 3.00 & 2.83 & 50 & .07 \\
\hline F03 & 55 & 88 & 44 & 3.39 & 33 & 3.22 & 3.57 & 3.50 & .85 & 3.09 & 3.67 & 3.33 & 3.33 & 3.07 & 3.26 & 3.53 & 3.38 & 3.13 & 3.83 & 75 & \\
\hline $\mathrm{EF} 04$ & 45 & 63 & 28 & 3.17 & 3.37 & 3.22 & 3.29 & 3.64 & .00 & 3.04 & 3.40 & 3.48 & 3.10 & 3.13 & 11 & 3.35 & 3.29 & 3.07 & 3.17 & 33 & 3.23 \\
\hline US & 50 & 81 & 50 & 3.39 & 70 & 3.44 & 3.79 & 3.82 & 15 & 3.30 & 3.73 & 3.48 & 48 & 3.47 & 05 & 1 & 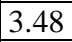 & 3. & 75 & 5 & \\
\hline F06 & 90 & 50 & 89 & 2.67 & 41 & 3.44 & 3.21 & 50 & .00 & 2.87 & 2.47 & 2.90 & 2.81 & 2.53 & 2.84 & 2.94 & 2.67 & 2.40 & 3.54 & 3.08 & .93 \\
\hline EF07 & .65 & .00 & 50 & 3.28 & 59 & 3.11 & 3.93 & 3.77 & .31 & 3.43 & 3.47 & .38 & 3.38 & 3.33 & 3.26 & 3.47 & 3.43 & 3.27 & 3.58 & .58 & 3.4 \\
\hline EF08 & 3.25 & .50 & 83 & 2.83 & 44 & 3.44 & 3.43 & 3.45 & 2.92 & 2.57 & 3.00 & 2.95 & 3.00 & 3.13 & 2.74 & 3.24 & 3.00 & 3.00 & 2.83 & 3.17 & .0 \\
\hline F09 & 3.20 & 2.56 & 3.22 & 2.94 & 48 & 3.11 & 3.50 & 3.32 & 2.69 & 2.35 & 2.93 & 2.86 & 3.05 & 2.87 & 2.95 & 3.35 & 2.90 & 3.07 & 2.83 & 2.67 & 95 \\
\hline 10 & 60 & 44 & 50 & 2.22 & 37 & 3.33 & 3.29 & 3.41 & 2.77 & 2.43 & 2.27 & 2.43 & 2.90 & 2.80 & 2.63 & 2.88 & 2.48 & 2.60 & 2.50 & .25 & .71 \\
\hline F11 & 3.30 & 69 & 3.22 & 3.11 & 3.48 & 3.56 & 3.36 & 3.64 & 3.00 & 3.04 & 3.27 & 3.33 & 3.10 & 3.20 & 3.16 & 3.47 & 3.00 & 2.87 & 3.54 & 3.58 & 3.25 \\
\hline EF12 & 2.95 & 2.25 & 3.06 & 2.94 & 3.22 & 3.00 & 3.50 & 3.14 & 2.54 & 2.52 & 2.53 & 2.81 & 2.29 & 2.47 & 2.74 & 3.06 & 2.90 & 2.80 & 3.29 & 3.08 & 2.85 \\
\hline SEF13 & 3.10 & 2.44 & 3.22 & 2.72 & 3.30 & 3.33 & 3.29 & 3.09 & 2.69 & 2.87 & 2.27 & 2.95 & 2.86 & 3.07 & 2.63 & 3.47 & 2.71 & 2.67 & 3.17 & 3.00 & 2.9 \\
\hline 14 & 3.25 & 2.63 & 3.11 & 2.78 & 3.41 & 3.33 & 2.93 & 3.32 & 2.85 & 2.91 & 2.53 & 3.05 & 2.67 & 2.73 & 2.79 & 3.24 & 3.19 & 3.00 & 3.21 & 3.25 & 3.01 \\
\hline & 2.80 & 2.31 & 2.8 & 2.83 & 3.33 & 3.56 & 3.71 & 3.73 & 3.00 & 2.78 & 2.33 & 3.10 & 2.67 & 3.13 & 3.26 & 3.59 & 3.19 & 2.93 & 2.92 & 2.83 & 3.0 \\
\hline EAN & 21 & 61 & .12 & 2.98 & 3.40 & 3.33 & 3.42 & 3.48 & 2.92 & 2.88 & 2.95 & 3.11 & 3.02 & 3.02 & 2.96 & 3.31 & 3.08 & 2.95 & 3.22 & 3.16 & 3.11 \\
\hline
\end{tabular}

Interestingly, the average of female respondents (locals and tourists) tended to have lower SE than male respondents did. Females, when in a TD, were more likely to have bad experience than the males do (Yang et al., 2017). The low response from females to Yang et.al.'s statement shows that they had more bad experience than men did in the TDs. Therefore, it is necessary to improve thesecurity and comfort for women in the TDs. According to respondents,the information they obtained from outside is the same as the real information in the research areas (see SEF04 in Table 4). Although the responses from males and females tended to be the same but the females' responseswere higher than males, due to the fact that females usually provided better for their tours compared to males (Yoo et al., 2017). Therefore, females responded more actively; in contrast to the previous statement, the respondents' responsesto recommendthe TDs to others were positive (see SEF05 in Table 4); responses from male respondents tended to be higher than female. A tourist recommending a TD can be caused by good experience he/she got during his/her visits (Antón et al., 2017). Female respondents, based on the previous statement (see SEF3 in Table 4), had worse experiences than males who were less likely to share their experiences. TD needs to have information centers so they can provide clear information and improve visitor knowledge (Shavanddasht et al., 2017; Ginting et al., 2021).

The respondents' responses to the statement in information centre was quite low (see SEF06 in Table 4) because of adequate information centre in the TDs except Bukit Kubu that had the information centre because it is managed by the private party (Figure 3). An information centre in a TD is essential not only to provide information about the TD for tourists, especially new tourists, but also to promote crafts and souvenirs made by local people (Ballantyne et al., 2009). In case of lower females' responses than males' onesare in line with the previous statement (see SEF04 in Table 4). This is also in line with the main respondents' statement: "The condition of the information center in Pasar Buah is inadequate. Its roof is mossy and loose. In addition, there is also a loose ceramic wall. So the place should have been repaired and maintained, but that hasn't been realized yet." (key respondent from local figure).

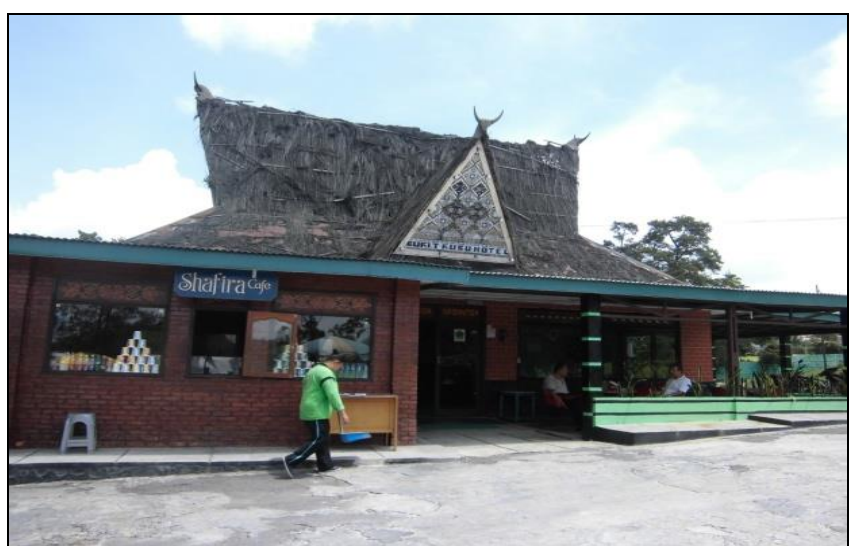

Figure 3. Information center at Bukit Kubu (Source: own collection, 2018)

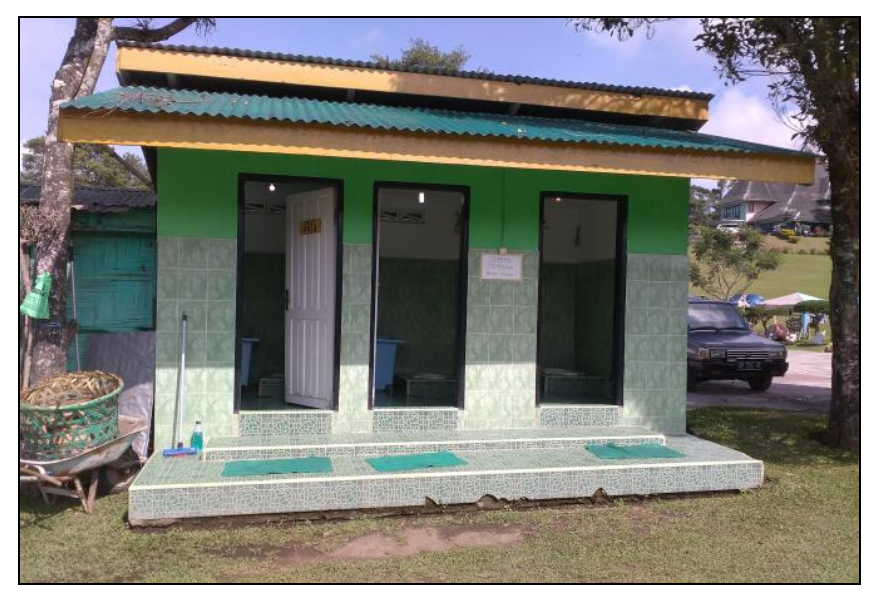

Figure 4. Toilet at Bukit Kubu (Source: own collection, 2018) 
With regard toself-confidence, male respondents are more confident than female are, especially who were visiting Bukit Gundaling and Desa Lingga because they thought that they spent masculine activities like picnic and sightseeing. Females proved to be more confident in Pasar Buah since their activities looked feminine. This phenomenon is in line with the opinion stated by Hallak et al. (2015) in which males are more confident doing masculine activities than women, and vice versa. The results were due to the striking differences between males and females of local respondents; for tourists, different confidence between males and females women were not conspicuous. For example, in the Sipiso-Piso waterfall, female tourists were more confident than male ones are although the TD offered masculine activities like climbing.

\section{Comfort}

Someone who is comfortable with a TD would be happy and have a high SE for the destination (Ujang, 2017). Based on the survey results, respondents thought they felt comfortable in the destinations (see SEF07 in Table 4); however, the responses from female respondents was lower than that of male respondents. The TDs that are not clean will make the tourists feel uncomfortable (Alfonzo, 2005). Respondents' responses to the statement about the trash in the tourism areasvaried; however, most respondents reacted negatively (se SEF08 in Table 4) because of, unfortunately, no adequate garbage can. Although females' responses were more positive than males' ones, there was no significant differences. Similar to previous statements, the statement about the seating facilities in the TDs was also responded fairly negative by the respondents (see SEF 9 in Table 4). Providing seats at the destinations were urgently needed to reduce the tourists' fatigue (Zakaria and Ujang, 2015). Interestingly, most female responses are much lower than male ones because physically females were weaker than males (Plamondon et al., 2017). Therefore, females were more easily tired and needed more seat than males did. Not much differentwith the previous statement, the clean and adequate public toilets were also responded negatively by the respondents (see SEF10 in Table 4) since toilets were the most important facilities in the TDs (Ja'afar et al., 2012). Unfortunately, in the research areas, toilet facilities were not clean and adequate (Figure 4). This is also in line with the main respondents' statement: "We will lose our appetite if we go to the toilet before eating. Every place has to build a restroom, and it is fine to pay for it if it is always well-maintained" (key respondent from Travel Association). Even though, public toilet facilities that are clean and have water available will provide comfort for tourists (Simanjuntak andSyahputra, 2021). Moreover, the responses from female respondents tended to be lower than the malesdid andthis is consistent with the statement by Wright-St et al. (2017) who argued that femaleswere more concerned and more self-care than males. Therefore, females needed clean and adequate toilets higher than males did.

Overall, male respondents felt more comfortable compared to female on the basis of cleanliness and physic; however, with reference with hygiene, females were more concerned than males although they were weak. The phenomenon is still in line with previous statements stating that the males' SE is higher than females' (Hallak et al., 2015; Ghanian et al., 2017). In case of self-confidence, females' low response was influenced by the striking differences between them, and males; among local repsondents, males were higher than females and among the tourists, the difference was not visible, especially in the Sipiso-Piso Waterfall, although the response from female tourists was higher than male ones.

\section{Safety}

Security is the most important factor for an attraction because tourists only need to visit a safe TD (Amir et al., 2015). Most respondents thought they felt safe while in the research areas (see SEF11 in Table 4). However, the response fro male respondents to the statement tended to be lower than that of female ones. This is in contrast to the results of research conducted by Yang et al. (2017) in which females were more likely to feel insecure in a TD than males.

When asked about the street lamps, some respondents responded slightly negative (see SEF12 in Table 4) because of no sufficient street lamps in the destinations; others argued street lamps were not so needed since they only stayed there only till afternoon. Actually, lamps in the TDs are a must to provide a sense of security for tourists when traveling and stimulate themto stay longer (Movahed et al., 2012; Murray and Feng, 2016). A respondent stated: "For the tourism development in $\mathrm{KR}$, the first crucial aspect to improve is accessibility. When we are travelling in the TDs in the afternoon, a crime is surely potential to occur. Thus, good accessibility is required where the provision of signs and of evening lamps in the TDs are really important" (Respondent: Head of Tourism Planning Program). With regard to the statement of Movahed et al., (2012) females did not respond anthusiastically indicating that, although females tended to feel more secure with securityrelated facilities, they were more concerned than males. Overall, for security-related statements, responses from both males and females were equally positive. Moreover, on average, there was no significant difference between the two sexes.

\section{Accessibility}

Accessibility becomes an essential aspect in SE and tourism in which tourists would more easily visit TDs that have good accessibility which stimulates them to come to tourist places (Chin et al., 2014); the accessibility is the pedestrian path. The physical quality of the pedestrian path is essential in making it easier for tourists to explore tourist destinations (Wibowo et al., 2021). Accessibility will affect visitors feel comfortable and not comfortable, which will affect visitors' SE (Jaelani et al., 2020). Most respondents (see SEF13 in Table 4) responded negatively about pedestrian paths in the TDs. Paths were not sufficient, had holes and bad surface, and were uncomfortable to walk on (Figure 5). Low responses came from females but males had different responses about paths and even in someTDs responses from both sexes were very significantly different because females prefered to walk and to relax than males (Pollard and Wagnild, 2017). Therefore, with poor condition of pedestrian paths, females felt uncomfortable and unhappy. Similarly, being asked about the condition of public transport, responses from most respondents tend to be negative (see SEF14 in Table 4) because public transports in the TDs were not 
adequate. Ideally, public transport in tourist areas is significant because it is associated with the ease of tourists to visit a tourist attraction (Amir et al., 2015). However, responses from males seemed to be lower than of the females'. Parking space would affect tourists' desire to return to the destinations they have ever visited (Snider et al., 2015). Unfortunately, not much different from the previous two statements, the statement related to the adequate parking lots were also responded negatively by the respondents (see SEF15 in Table 4) since parking areas, for instance in Bukit Kubu, were not sufficient. The statement is in line with the following statement: "Inadequate parking area in Berastagi is a crucial problem. No space for loading and unloading local products often disturbs tourists. Local police also applied traffic simulation to overcome the crowded traffic flow, that is, cars are not allowed to pass and park any longer in Brastagi" (Respondent: Hotel Manager). Interestingly from all areas of study, for accessibilityrelated statements, females tend to be higher than males. Only in Bukit Gundaling and Desa Lingga, females were lower than males. However, self-efficacy between the two sexes, females' self-efficacy is noted to be lower, so, in this case, such statement is not applicable in the research areas (Hallak et al., 2015).

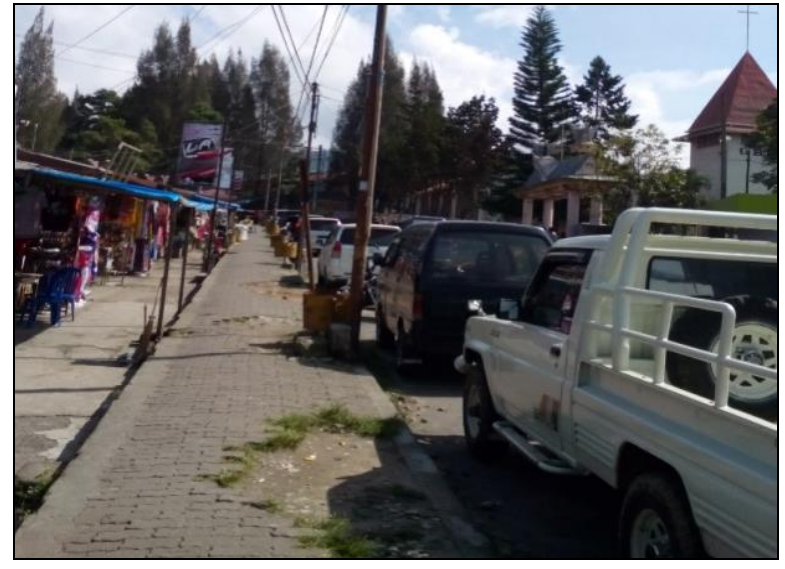

Figure 5. Pedestrian path in Pasar Buah (Source: own collection, 2018)

\section{CONCLUSION}

Self-Efficacy (SE) refers to a person's belief about his ability to well perform an activity in a place. In this study, gender affects the level of self-efficacy (LSE) in tourist destinations especially for local people. The level of selfefficacy (LSE) for females is not always lower than males. The tourists' activities which are categorized as masculine proved that the females' SE is higher than males. However, what needs to be examined more deeply is related to the aspects that affect the LSE since theoretically, the males' SE proved to be higher than females are only found among local people. The differences can be influenced by the respondents' levels of education and age.

Age and education are influential for SE because, for instance, a person who is old, has lower SE than that of younger one; someone with a lower education has lower SE than any other person who has higher education. Furthermore, in the development of tourism which is based on the tourists's SE, preference of gender does not need to be considered. However, if the development of tourism is done on the basis locals' SE, then the preference of gender is really needed. The high level of SE will increase visitor satisfaction with the place. The further research will be directed to other tourist's destinations which are especially located in the urban areas in which the results are hoped to be different with this research and the preferences of the urban community will certainly differ from that of the rural community.

\section{Acknowledgement}

The Authors would acknowledge their gratitude to the Indonesian Ministry of Research, Technology, and Higher Education for its financial support and to the Universitas Sumatra Utara (USU) for its TALENTA scheme of PUU in the Year 2017 with Grant Number: 42/UN5.2.3.1/PPM/KPTALENTA USU/2017. We would also thank the USU's Sustainable Tourism Working Group andthe students of the USU's Department of Architecture, Faculty of Engineering.

\section{REFERENCES}

Alfonzo, M.A. (2005). To walk or not to walk? The hierarchy of walking needs. Environment and Behavior, 37(6), 808-836. http://dx.doi.org/10.1177/0013916504274016

Amir, A.F., Ismail, M.N.I., \& See, T.P. (2015). Sustainable tourist environment: perception of international women travelers on safety and security in Kuala Lumpur. Procedia-Social and Behavioral, Sciences 168, 123-33. https://doi.org/10.1016/j.sbspro.2014.10.218

Antón, C., Camarero, C., \& Laguna-García, M. (2017). Towards a new approach of destination loyalty drivers: satisfaction, visit intensity and tourist motivations. Current Issues in Tourism,20(3), 238-60. https://doi.org/10.1080/13683500.2014.936834

Ballantyne, R., Hughes, K., \& Ritchie, B.W. (2009). Meeting the needs of tourists: the role and function of australian visitor information centers. Journal of Travel \& Tourism Marketing, 26(8), 778-94. https://doi.org/10.1080/10548400903356178

Bandura, A. (1997). Self-Efficacy: the exercise of control. Choice Reviews Online, 35. Macmillan. https://doi.org/10.5860/CHOICE.35-1826

Chin, Chee-Hua, Lo, May-Chiun, Songan, P., \& Nair, V. (2014). Rural tourism destination competitiveness: a study on annahrais longhouse homestay, Sarawak. Procedia-Social and Behavioral Sciences, 144, 35-44. https://doi.org/10.1016/j.sbspro.2014.07.271

Eusuf, M.A., Mohit, M.A., EUSUF, M.M.R., \& Ibrahim, M. (2014). Impact of outdoor environment to the quality of life. ProcediaSocial and Behavioral Sciences 153, 639-54. https://doi.org/10.1016/j.sbspro.2014.10.096

Ghanian, M., Ghoochani, O., \& Crotts, J. (2017). Analyzing the motivation factors in support of tourism development: the case of rural communities in Kurdistan Region of Iran. Journal of Sustainable Rural Development, 1(2): 137-48. https://doi.org/10.29252/jsrd.01.02.137

Ginting, N. (2016). How Self-Efficacy enhance heritage tourism in Medan historical corridor, Indonesia. Procedia-Social and Behavioral Sciences, 234, 193-200. https://doi.org/10.1016/j.sbspro.2016.10.234

Ginting, N., Rahman, N.V., \& Nasution, A.D. (2017). Increasing tourism in Karo district, Indonesia based on place identity. Environment-Behaviour Proceedings Journal, 2(5), 177-84. https://doi.org/10.21834/e-bpj.v2i5.629

Ginting, N. (2018). Being manageable through self-efficacy in heritage tourism development. Asian Journal of Quality of Life, 3(11): 29-38. https://doi.org/10.21834/ajqol.v3i11.119

Ginting, N., Rahman, V.N., Nasution, A.D., \& Dewi, N.A. (2021). Geotourism Development Through the Public Facilities in Geotrail Bakkara, Toba Caldera Geopark. GeoJournal of Tourism and Geosites, 37(3), 914-920. https://doi.org/10.30892/gtg.37324-726 
Gist, M.E., \& Mitchell, T.R. (1992). Self-Efficacy: a theoretical analysis of its determinants and malleability. Academy of Management Review, 17(2), 183-211. https://doi.org/10.5465/amr.1992.4279530

Gu, H., \& Ryan, C. (2008). Place attachment, identity and community impacts of tourism - the case of a Beijing Hutong. Tourism Management, 29(4), 637-47. https://doi.org/10.1016/j.tourman.2007.06.006

Guo, Y., Kim, S., \& Chen, Y. (2014). Shanghai residents' perceptions of tourism impacts and quality of life. Journal of China Tourism Research, 10(2), 142-64. https://doi.org/10.1080/19388160.2013.849639

Hallak, R., Assaker, G., \& O'Connor, P. (2014). Are family and nonfamily tourismbusinesses different? an examination of the entrepreneurial self-efficacy--entrepreneurial performance relationship. Journal of Hospitality \& Tourism Research, 38(3), 388-413. https://doi.org/10.1177/1096348012461545

Hallak, R., Assaker, G., \& Lee, G. (2015). Tourism entrepreneurship performance: the effects of place identity, self-efficacy, and gender. Journal of Travel Research, 54(1), 36-51. https://doi.org/10.1177/0047287513513170

Hung, K., \& Petrick, J.F. (2012). Testing the effects of congruity, travel constraints, and self-efficacy on travel intentions: an alternative decision-making model. Tourism Management, 33(4), 855-67. https://doi.org/10.1016/j.tourman.2011.09.007

Ja'afar, N.H., Sulaiman, A.B., \& Shamsuddin, S. (2012). The contribution of landscape features on traditional streets in Malaysia. Procedia-Social and Behavioral Sciences, 50, 643-56. https://doi.org/10.1016/j.sbspro.2012.08.067

Jaelani, E., \& Erdinaya, L.K. Rohanda, \& Perbawasari, S. (2020). The Religious Meaning of Equestrian and Archery Sport Tourism: A Phenomenological Analysis. GeoJournal of Tourism and Geosites, 28 (1), 246-256. https://doi.org/10.30892/gtg.28119-466

Movahed, S., Azad, S.P., \& Zakeri, H. (2012). A safe pedestrian walkway; creation a safe public space based on pedestrian safety. Procedia-Social and Behavioral Sciences, 35, 572-85. https://doi.org/10.1016/j.sbspro.2012.02.124

Murray, A.T., \& Feng, X. (2016). Public street lighting service standard assessment and achievement. Socio-Economic Planning Sciences, 53, 14-22. https://doi.org/10.1016/j.seps.2015.12.001

Piperopoulos, P., \& Dimov, D. (2015). Burst bubbles or build steam? entrepreneurship education, entrepreneurial self-efficacy, and entrepreneurial intentions. Journal of Small Business Management, 53(4), 970-85. https://doi.org/10.1111/jsbm.12116

Plamondon, A., Larivière, C., Denis, D., Mecheri, H., Nastasia, I., \& IRSST MMH research group. (2017). Difference between male and female workers lifting the same relative load when palletizing boxes. Applied ergonomics, 60, 93-102. https://doi.org/10.1016/j.apergo.2016.10.014

Pollard, T.M., \&Wagnild, J.M. (2017). Gender differences in walking (for leisure, transport and in total) across adult life: a systematic review. BMC Public Health, 17(1), 341. https://doi.org/10.1186/s12889-017-4253-4

Propst, D.B., \& Koesler, R.A. (1998). Bandura goes outdoors: role of self-efficacy in the outdoor leadership development process. Leisure Sciences, 20(4), 319-44. https://doi.org/10.1080/01490409809512289

Samimi, A.J., Sadeghi, S., \& Sadeghi, S. (2011). Tourism and economic growth in developing countries: P-VAR approach. Middle-East Journal of Scientific Research, 10(1), 28-32. https://idosi.org/mejsr/mejsr10(1)11.htm

Schwarzer, R. (2014). Self Efficacy - thought control of action. Taylor \& Francis. https://doi.org/10.4324/9781315800820

Shavanddasht, M., Karubi, M., \& Sadry, B.N. (2017). An Examination of the Relationship Between Cave Tourists'motivations and Satisfaction: The Case of Alisadr Cave, Iran. GeoJournal of Tourism \& Geosites, 20(2). http://gtg.webhost.uoradea.ro/2017_2_vol_20.html

Simanjuntak, W.O.R., \& Syahputra, M.H.I. (2021). Community Empowerment in Developing Kampoeng Lama Tourism Village as an Educational Tourism Destination. Asian Journal of Management, Entrepreneurship and Social Science, 1(1), 92-102. https://doi.org/10.98765/ajmesc.v1i1.29

Snider, A., Luo, S., Hill, J., \& Herstine, J. (2015). Perceptions of availability of beach parking and access as predictors of coastal tourism. Ocean \& Coastal Management, 105, 48-55. https://doi.org/10.1016/j.ocecoaman.2014.12.022

Stajkovic, A.D., Bandura, A., Locke, E.A., Lee, D., \& Sergent, K. (2018). Test of three conceptual models of influence of the big five personality traits and self-efficacy on academic performance: a meta-analytic path-analysis. Personality and Individual Differences, 120, 238-45. https://doi.org/10.1016/j.paid.2017.08.014

Stedman, R.C. (2002). Toward a social psychology of place: predicting behavior from place-based cognitions, attitude, and identity. Environment and Behavior, 34(5), 561-81. https://doi.org/10.1177/0013916502034005001

Stratan, A., Perciun, R., \& Gribincea, C. (2015). Identifying cultural tourism potentials in Republic of Moldova through cultural consumption among tourists. Procedia-Social and Behavioral Sciences, 188, 116-21. https://doi.org/10.1016/j.sbspro.2015.03.346

Twigger-Ross, C.L, \& Uzzell, D.L. (1996). Place and identity processes. Journal of Environmental Psychology, 16(3), 205-220. https://doi.org/10.1006/jevp.1996.0017

Twigger-Ross, C.L., Bonaiuto, M., \& Breakwell, G.M. (2003). Identity theories and environmental psychology. psychological theories for environmental issues. Ashgate, Surrey, United Kingdom. https://www.researchgate.net/publication/313584290_Identity_theories_ and_environmental_psychology

Ujang, N. (2017). Place attachment and continuity of urban place identity. Asian Journal of Environment-Behaviour Studies, $2(2), 117$. https://doi.org/10.21834/aje-bs.v2i2.182

Wang, S., \& Xu, H. (2015). Influence of place-based senses of distinctiveness, continuity, self-esteem and self-efficacy on residents' attitudes toward tourism. Tourism Management, 47, 241-50. https://doi.org/10.1016/j.tourman.2014.10.007

Wang, S., \& Chen, J.S. (2015). The influence of place identity on perceived tourism impacts. Annals of Tourism Research, 52, 16-28. https://doi.org/10.1016/j.annals.2015.02.016

Wibowo, T.W., Santosa, S.H., Susilo, B., \& Purwanto, T.H. (2021). Revealing tourist hotspots in Yogyakarta city based on social media data clustering. GeoJournal of Tourism and Geosites, 34(1), 218-225. https://doi.org/10.30892/gtg.34129-640

Wright-St Clair, V.A., Rapson, A., Kepa, M., Connolly, M., Keeling, S., Rolleston, A., Teh, R., Broad, J.B., Dyall, L., Jatrana, S., Wiles, J., Pillai, A., Garrett, N., \& Kerse, N. (2017). Ethnic and gender differences in preferred activities among Māori and non-Māori of advanced age in New Zealand. Journal of cross-cultural gerontology, 32(4), 433-446. https://doi.org/10.1007/s10823-017-9324-6

Yang, E.C.L., Khoo-Lattimore, C., \& Arcodia, C. (2017). A systematic literature review of risk and gender research in tourism. Tourism Management, 58, 89-100. https://doi.org/10.1016/j.tourman.2016.10.011

Yoo, C.W., Goo, J., Huang, C.D., Nam, K., \& Woo, M. (2017). Improving travel decision support satisfaction with smart tourism technologies: a framework of tourist elaboration likelihood and self-Efficacy. Technological Forecasting and Social Change, 123, 330-41. https://doi.org/10.1016/j.techfore.2016.10.071

Zakaria, J., \& Ujang, N. (2015). Comfort of walking in the city center of Kuala Lumpur. Procedia-Social and Behavioral Sciences, 170 , 642-52. https://doi.org/10.1016/j.sbspro.2015.01.066 